\title{
Maintenance of mesenchymal stem cells culture due to the cells with reduced attachment rate
}

\author{
N. S. Shuvalova, O. A. Maslova, O. M. Sukhorada, \\ O. G. Deryabina, V. A. Kordium \\ Institute of Molecular Biology and Genetics, NAS of Ukraine \\ 150, Akademika Zabolotnogo Str., Kyiv, Ukraine, 03680 \\ riyena@yandex.ru
}

\begin{abstract}
Aim. The classic detachment techniques lead to changes in cells properties. We offer a simple method of cultivating the population of cells that avoided an influence on the surface structures. Methods. Mesenchymal stem cells (MSC) from human umbilical cord matrix were obtained and cultivated in standard conditions. While substituting the culture media by a fresh portion, the conditioned culture medium, where the cells were maintained for three days, was transferred to other culture flacks with addition of serum and growth factors. Results. In the flacks, one day after medium transfer, we observed attached cells with typical MSC morphology. The cultures originated from these cells had the same rate of surface markers expression and clonogenic potential as those replated by standard methods. Conclusions. MSC culture, derived by preserving the cells with reduced attachment ability, actually has the properties of "parent» passage. Using this method with accepted techniques of cells reseeding would allow maintaining the cells that avoided an impact on the cell surface proteins.
\end{abstract}

Keywords: MSC, cultivation, cells with reduced attachment ability.

Introduction. Mesenchymal stem cells (MSC) are considered to be one of the most promising instruments of cell therapy. However, their cultivation is related to some difficulties, which have not been overcome to a full degree. Therefore, the methods of isolating MSC from tissues, their cultivation, passaging, and facilitating the retention of multipotency are actively elaborated and improved [1-3].

In the tissues of organism MSC are located in the complex three-dimensional system, where their surface apparatus is adjusted to receive and process the signals from outside. The extracellular matrix and surrounding cells create unique physical and chemical conditions, determining MSC behavior $[4,5]$. During the cultivation in the monolayer the cells get accustomed to specific conditions and released from centralized regulation by the neuroimmune and humoral factors [6].

(C) Institute of Molecular Biology and Genetics, NAS of Ukraine, 2013
While passaging the culture the cells are forced to detach from the "parent" substrate. This is achieved using the solutions, containing proteolytic enzymes, enzymefree solutions and special mechanical technologies [2]. The most wide-spread and rather efficient enzymatic methods of detaching the cells from the substrate are deemed to be the solutions of trypsin $(0.25 \%)$ and versene $(0.02 \%)$ [2]. However, during this procedure the proteins and glycoproteins on the cell surface are inevitably damaged. The use of proteolytic enzymes and the effect of mechanical manipulations during the replating procedure compels the cells to lose relevant homing receptors and attachment molecules. It has a proven negative effect on the stem potential of MSC [3-8]. Passage by passage the cells change their properties, lower the degree of multipotency and homing ability [9]. Therefore, various variants of cultivating MSC without any obligatory detachment are suggested, for instance, the application of culture flasks of a spe- 
cial form, which can stretch and increase the surface area with the enlargement of cell mass $[10,11]$, or the cultivation in three-dimensional conditions on different carriers [12]. These methods are efficient, however they require additional technical possibilities, complicating the work and rather expensive.

The current work was aimed at the optimization of MSC cultivation conditions to preserve the cells with undamaged surface apparatus and, therefore, more relevant by their properties to the cells of the first passages than the cells after numerous replating procedures.

Materials and Methods. Cell isolation. Umbilical cords, collected after normal vaginal delivery, were provided by the Kyiv maternity clinic No. 5 . The cells were isolated using the combined method [13]. The umbilical cords were kept in the solutions of antibiotics (the mixture of $1 \mathrm{mg} / \mathrm{ml}$ penicillin (Arterium, Ukraine) and $1 \mathrm{mg} / \mathrm{ml}$ streptomycin (Arterium)) for $20 \mathrm{~min}$ and washed in PBS. Then they were cut in fragments. To avoid the potential contamination of MSC population by endothelial cells, the vessels were removed. The obtained fragments were washed, minced and incubated in the solution of enzymes (collagenase type I (Sigma, USA), 200 units/ml, hyaluronidase type IV (Sigma), 400 units $/ \mathrm{ml}$ ) at $37^{\circ} \mathrm{C}$ for $20-60$ min depending on the matrix density. After the incubation the tissue fragments were transferred into the flasks with the cultural medium (DMEM with low glucose content (PAA, Austria), and with penicillin (Arterium) and streptomycin (Arterium) $100 \mu \mathrm{g} / \mathrm{ml}$ each, $2 \mathrm{mM} \mathrm{L}$-glutamine (Sigma), 10 nM FGF2 (Refibrol, PharmBiotek, Ukraine) and $10 \%$ solution of fetal bovine serum $(P A A)$ ).

The solution of enzymes was collected and centrifuged for $7 \mathrm{~min}$ at 1,000 rpm. The precipitate obtained was added PBS with subsequent centrifugation in the same mode. The precipitate obtained was introduced into flasks with the abovementioned cultural medium.

The attached fibroblast-like cells - single or clones of 2-6 cells - could be observed on the bottom of the culture flasks $1-3$ days later. Two days after the cell registration the medium was replaced by the fresh portion.

Cultivation. The cultivation was conducted in $\mathrm{CO}_{2}-$ incubator $\left(37^{\circ} \mathrm{C}, 5 \% \mathrm{CO}_{2}\right)$. MSC were cultivated in the above described medium in plastic flasks with the area of 25 and 75 square $\mathrm{cm}(P A A)$. At all the passages the medium was changed every 3 days.

When the monolayer confluence reached $\sim 70 \%$, the cells were passed using the mixture of trypsin $(0.25 \%)(P A A)$ and versene $(0.02 \%)(1: 1)$.

Cultivation optimization. While replacing the cultural medium with the fresh portion the conditioned medium was collected, transferred into a new flask with the addition of fetal bovine serum $(1 \mathrm{ml}$ per $10 \mathrm{ml}$ of the obtained medium) and FGF2 (per $0.0025 \mu \mathrm{g} / \mathrm{ml}$ ).

Microscopy. Cell morphology was examined with light microscopy using the Leica DMIL inverted microscope and imaged with Canon PowerShot 640A camera.

Results and Discussion. It is known that during a specific phase of the cell cycle, for instance, prior to the division, the degree of cell attachment to the substrate decreases [14].

MSC culture (during routine cultivation) is asynchronous. Therefore, cells not do not proceed through the stages of cell cycle simultaneously, which presupposes the risk of losing some cells at standard replating, when the medium, where the cells were maintained, is removed from the culture flask. According to the suggested method, the conditioned medium, in which the culture has been growing for some time, is transferred to another culture flask (for instance, during medium changing). This medium is added a portion of serum and growth factors.

On the following day there is evident attachment of the cells, which might have been in less adhesive state. To reach the higher concentration of cells the obtained medium may also be centrifuged, thus precipitating the cells and immediately placing the obtained precipitate into the flask with the medium.

Taking into account the individual features of cultures, obtained from different donors, one can note 10-20 "attachment places" on average on the bottom of the culture flask containing 1-10 cells. These clones are viable and actively proliferating. In seven-ten days the number of cells increases three-fold on average. Approximately two weeks after the first detection of the cells, the clones acquire size and confluence sufficient to be passed using standard methods.

The morphology of the cells, obtained by the method of preserving the conditioned medium, is typical 

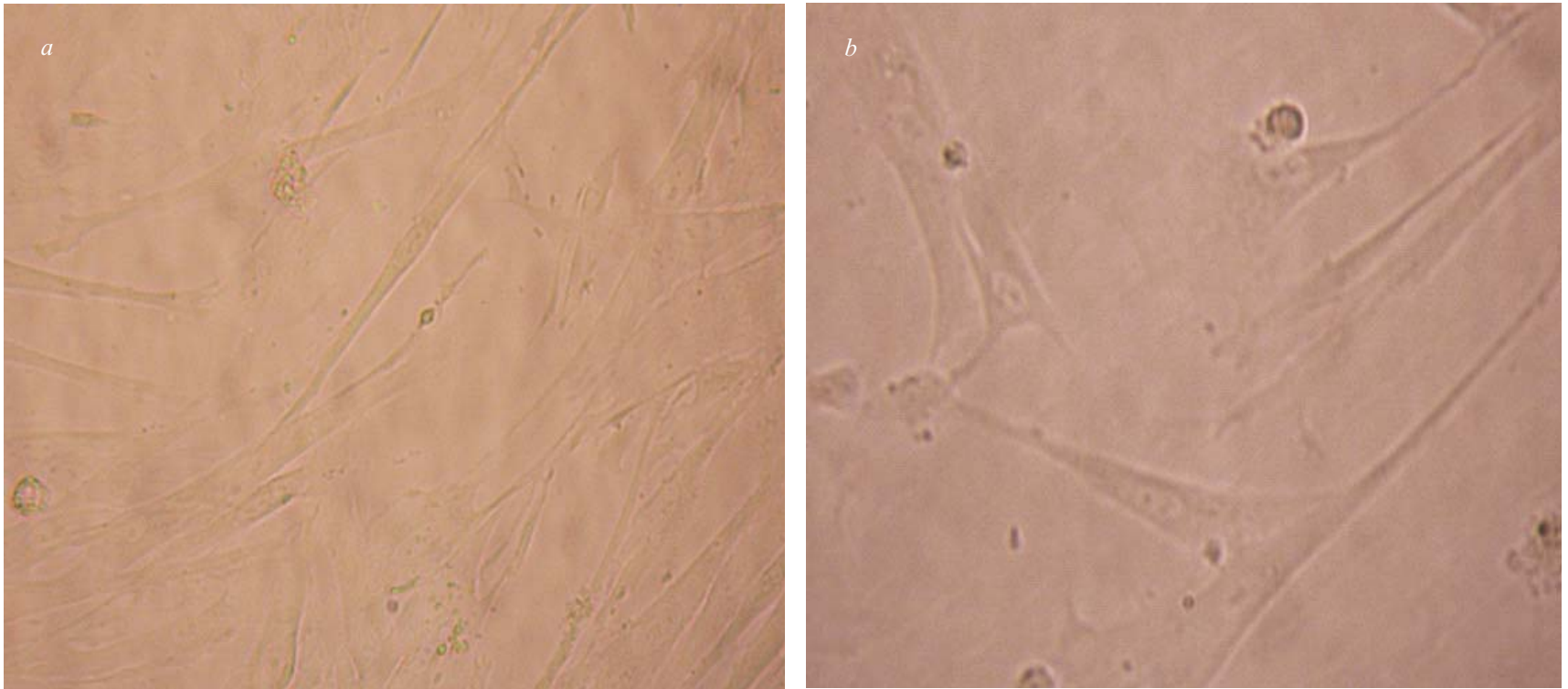

Comparison of the morphology of cell cultures (48 hours) and the cells that have passed the standard procedure passaging, 2nd passage b cells obtained by transferring the medium where they were cultivated for 3 days, in another culture vial 1 st arcade. MSCs are alive, unstained; X100

for MSC. Taking into account the discrepancies in the number of cells, obtained by the above described method, and the cells, replated by standard methods using the solutions of trypsin $(0.25 \%)$ and versene $(0.02 \%)$ it is possible to state that generally the cells of the derived culture preserve the morphology, typical for the cells of the initial culture (Fig.). The degree of surface markers expression is similar to the one in cultures, replated by the standard method (over $75 \%$ population are CD105, CD73, CD90 markers positive).

The expression of the surface marker proteins was determined by staining with fluorescent-labeled antibodies (United States Biological, USA) on BD FACS Aria cell sorter (State Institute of Genetic and Regenerative Medicine, NAMS Ukraine) (data not shown).

The damaging effect of the multiple obligatory detachment of cells from the substrate during the culture passaging is described in detail in the works $[7-9,15]$.

The method of using the conditioned medium, suggested by us, helps to preserve an additional amount of cells and to reduce the degree of negative effect on MSC culture.

Conclusions. The main advantage of the suggested approach is the fact that the culture, obtained via upholding the cells, spontaneously detached during the replacement of the cultural medium, actually preserves the properties of the initial passage cells. As only a part of the population is remarkable for decreased attachment level, the described method would be a reasonable addition to the standard method. It would provide permanent support to the cell population, which evaded the impact of the standard procedure of passaging on proteins and glycoproteins of the surface apparatus.

\section{Н. С. Шувалова, О. А. Маслова, Е. М. Сухорада, О. Г. Дерябина B. А. Кордюм}

Возможность поддержания культуры мезенхимальных стволовых клеток за счет клеток со сниженной степенью адгезии

Институт молекулярной биологии и генетики НАН Украины Ул. Академика Заболотного, 150, Киев, Украина, 03680

Резюме

Цель. Использование классических методик для открепления мезенхимальных стволовых клеток (МСК) от субстрата приводит к изменению их свойств. В данном сообщении предложен простой и доступный способ сохранения популяциии клеток, избежавших влияния на поверхностный аппарат. Материаль и методы. МСК из матрикса пупочного канатика человека получали и культивировали по стандартной методике. При замене культуральной среды на свежую пориию кондичионированную среду, в которой культура находилась в течение трех дней, предположительно содержашую спонтанно открепившиеся клетки, переносили в другой культуральный сосуд, добавляя сыворотку и ростовые факторы. Результаты. Через сутки после переноса кондиционированной среды на дне сосуда можно было обнаружить прикрепленные клетки типичной для МСК морфологии, имеющие степень экспрессии поверхностных маркеров и клоно- 
генный потенциал, аналогичные таким культур, пересеянных по стандартной методике. Выводы. Дочерняя культура, полученная в результате сохранения клеток, спонтанно открепившихся в процессе замены культуральной среды, фактически, сохраняет свойства клеток исходного пассажа. Метод целесообразно при менять дополнительно к стандартной методике пассирования. Это позволит постоянно иметь пул клеток, избежавиих влияния классической процедуры пассирования на белки и гликопротеины поверхности клетки.

Ключевые слова: МСК, культивирование, клетки со сниженной степенью адгезии.

\section{Н. С. Шувалова, О. О. Маслова, О. М. Сухорада, О. Г. Дерябіна, B. А. Кордюм}

Можливість підтримання культури мезенхімальних стовбурових клітин за рахунок клітин зі зниженим ступенем адгезії

\section{Резюме}

Мета. Застосування класичних методик для відкріплення мезенхімальних стовбурових клітин (МСК) від субстрату призводить до змін їхніх властивостей. У даному повідомленні запропоновано простий $і$ доступний спосіб збереження популяиії клітин, щуо уникли впливів на поверхневий апарат. Матеріали і методи. МСК з матриксу пупкового канатика людини отримували $і$ культивували за стандартною методикою. При заміні культурального середовища на свіжу пориію кондиціоноване середовище, у якому культури знаходилися впродовж трьох днів і яке потенційно містило спонтанно відкріплені клітини, переносили в інший культуральний посуд, додаючи сироватку та ростові фактори. Результати. Через добу після перенесення середовища на дні культурального посуду можна було спостерігати прикріплені клітини типової для МСК морфології, які мали ступінь експресії поверхневих маркерів та клоногенний потенціал, аналогічні таким у культур, пасованих за стандартною методикою. Висновки. Дочірня культура, отримана внаслідок збереження клітин, які спонтанно відкріпились у прочесі заміни культурального середовища, фактично, зберігає властивості клітин вихідного пасажу. Запропонований метод доиільно застосовувати додатково до стандартної методики пасування. Це дозволить постійно мати пул клітин, які уникли почкоджуючих впливів на білки і глікопротеїни поверхні клітини.

Ключові слова: МСК, культивування, клітини зі зниженим ступенем адгезіі.

\section{REFERENCES}

1. Nombela-Arrieta C., Ritz J., Silberstein L. The elusive nature and function of mesenchymal stem cells // Nat. Rev. Mol. Cell Biol.-2011.-12, N 2.-P. 126-131.

2. Heng B. C., Cowan C. M., Basu S. Comparison of enzymatic and non-enzymatic means of dissociating adherent monolayers of mesenchymal stem cells // Biol. Proced. Online.-2009.-11.P. 161-169.

3. Rombouts W. J., Ploemacher R. E. Primary murine MSC show highly efficient homing to the bone marrow but lose homing ability following culture // Leukemia.-2003.-17, N 1.-P. 160-170.

4. Augello A., Kurth T. B., De Bari C. Mesenchymal stem cells: a perspective from in vitro cultures to in vivo migration and niches // Eur. Cell Mater.-2010.-20.-P. 121-133.

5. Reilly G. C., Engler A. J. Intrinsic extracellular matrix properties regulate stem cell differentiation // J. Biomech.-2010.-43, N 1.P. 55-62.

6. Toyoda M., Takahashi H., Umezawa A. Ways for a mesenchymal stem cell to live on its own: maintaining an undifferentiated state ex vivo // Int. J. Hematol.-2007.-86, N 1.-P. 1-4.

7. Wagner W., Horn P., Castoldi M., Diehlmann A., Bork S., Saffrich R., Benes V., Blake J., Pfister S., Eckstein V., Ho A. D. Replicative senescence of mesenchymal stem cells: a continuous and organized process // PLoS One.-2008.-3, N 5.-e2213.

8. Angelucci S., Marchisio M., Di Giuseppe F., Pierdomenico L., Sulpizio M., Eleuterio E., Lanuti P., Sabatino G., Miscia S., Di Ilio $C$. Proteome analysis of human Wharton's jelly cells during in vitro expansion // Proteome Sci.-2010.-8.-P. 18.

9. Sarkar D., Spencer J. A., Phillips J. A., Zhao W., Schafer S., Spelke D. P., Mortensen L. J., Ruiz J. P., Vemula P. K., Sridharan R., Kumar S., Karnik R., Lin C. P., Karp J. M. Engineered cell homing // Blood.-2011.-118, N 25.-e184-191.

10. Majd H., Wipff P. J., Buscemi L., Bueno M., Vonwil D., Quinn T. M., Hinz B. A novel method of dynamic culture surface expansion improves mesenchymal stem cell proliferation and phenotype // Stem Cells.-2009.-27, N 1.-P. 200-209.

11. Majd H., Quinn T. M., Wipff P. J., Hinz B. Dynamic expansion culture for mesenchymal stem cells // Methods Mol. Biol.-2011.698.-P. 175-188.

12. Witte H., Stubenrauch M., Frober U., Fischer R., Voges D., Hoffmann $M$. Integration of 3-D cell cultures in fluidic microsystems for biological screenings // Eng. Life Sci.-2011.-11, N 2.P. 140-147.

13. Tong C. K., Vellasamy S., Tan B. C., Abdullah M., Vidyadaran S., Seow H. F., Ramasamy R. Generation of mesenchymal stem cell from human umbilical cord tissue using a combination enzymatic and mechanical disassociation method // Cell Biol. Int.2011.-35, N 3.-P. 221-226.

14. Thery M., Bornens M. Cell shape and division // Curr. Opin. Cell. Biol.-2006.-18, N 6.-P. 648-657.

15. Bruder S. P., Jaiswal N., Haynesworth S. E. Growth kinetics, self-renewal, and the osteogenic potential of purified human mesenchymal stem cells during extensive subcultivation and following cryopreservation // J. Cell. Biochem.-1997.-64, N 2.P. 278-294. 